\title{
HRM PRACTICES ON FOREIGN-OWNED COMPANIES IN HUNGARY
}

\begin{abstract}
This paper sought to answer the question of how best human resource practices can support organisations in the current phase of internationalisation while still maintaining the local standards of the hosting country? In attempting to answer this question, the paper studied the HRM practices of Foreign-Owned Companies and Hungary's Socioeconomic environment. The study revealed that the Hungarian cultural society was more independent, and power hierarchy was not entrenched in the organisational cultures, highly individualistic, masculine, intolerant towards taking risks, realistic, and culturally restrained. The paper concluded that the increased FDIs and multinational companies in Hungary posed a great challenge to employees' effective and efficient management while still maintaining the host country's local standards.
\end{abstract}

Keywords: international HRM; labour markets; foreign direct investments; foreign-owned companies, Hungary.

\section{INTRODUCTION}

Currently, the business environment is faced with globalisation and technological changes. These changes make the management of companies more uncertain and complex (Chegri et al., 2021). Additionally, human resource management's vibrancy and globalisation have set off activities targeting human resource management at the international level. Employees have agreed to work away from their home countries, and organizations have worked hard to meet their goals in order to gain a competitive advantage. Consequently, International Human Resource Management (IHRM) has gained popularity in handling human resources at multinational companies (MNCs) through recruiting, training, and performance appraisal. However, Thill et al. (2016) argue that human resources management has become more complex and could influence employment instability. This is due to the different approaches and practices of human resource management, causing differences between foreign-owned and domestically owned companies. Conditions such as the host country's culture, the product's size, and national

\footnotetext{
${ }^{1}$ Ayman Balawi, Ph.D. candidate, Faculty of Business and Economics, University of Pécs, Pécs, Rákóczi út 80, 7622, Hungary; e-mail: Aymanalb2004@gmail.com (corresponding author). ORCID: 0000-0002-4500-5337.

2 Esther W. Wachira, Ph.D. candidate, Faculty of Business and Economics, University of Pécs, Pécs, Rákóczi út 80, 7622, Hungary; e-mail: E.wachira2012@gmail.com. ORCID: 0000-0002-4834617X.
} 
policies for the product may force the MNCs to develop and adopt different corporate strategies that align with the local host country's (Poór et al., 2017; Radulescu et al., 2019). Subsequently, this leads to the question of how best human resource practices can support organisations in the current internationalisation phase while still maintaining the local standards of the host country.

Internalisation of organisations attributes the competitiveness of businesses to managing employees and the development of HR functions. A greater degree of qualified top management involvement is a significant concern to maintain a locally and internationally competitive advantage (Bembenek, 2014). Moreover, organisations aiming to invest across boundaries now assume strategic importance in employing the right people in suitable positions, which is instrumental in the organisation's strategies, performance, and growth. Thill et al. (2016) posit that the role of human resource management in foreign companies covers the strategy dealing with executing organisational strategies and objectives, considering the host country's cultural influences.

\subsection{Development of HRM}

Historically, the idea of human resource management was developed and adopted as early as 1980 in North America. After the fall of the socialist system in Europe, EU countries, especially from the east, were faced with the challenge of skilled workers' migration to Western European countries. Hence, there was a shortage of managerial, trained professionals, and skilled workers. During this period, Western Europe attached importance to human resource management due to a lack of comprehensive systematic personnel functions (Scullion et al., 2007; Karoliny et al., 2009). In the '90s, most CEE countries emphasised the concept and practice of human resource management under the state's watch. Therefore, the personnel department consisted of two sections headed by the personnel manager and the finance director (Thill et al., 2016). This meant that all issues related to the employees, including their welfare, promotion, and recruitment to management positions, were closely monitored by the government, as back then, human resource management was not regarded as a profession (Mazur, Walczyna, 2020). Morley et al. (2016) argued that this management mode was not favourable to the economy's growth as it did not follow free-market principles.

The business environment and labour markets have witnessed a notable change in former socialist countries' business and human resource management practices. The entry of multinational corporations shaped domestic human resource management by introducing basic salary systems, as well as the learning and acceptance of foreign languages and cultures. However, during the initial stages of HR development, the local markets could not fulfil the HR needs and capacity anticipated by international companies. Poór et al. (2015) argued that the implications of HRM practices vary in different countries due to different traditions, cultures, political stability, and economic development. Thill et al. (2016) further supported this view and hypothesised that human resource management is implemented and performed differently in different countries, even in the European Union.

In Hungary, during the socialist era, most of the key positions in organisations were kept under the keen eye of the Hungarian Socialist Workers Party and the state bureaucracy (Wolfe, Poór, 1992). According to Michael et al. (2016) and Poór (2009), by the year 2005, Hungary had entirely accepted the concept of human resource management and had begun designing HRM strategies with major decision-making being the responsibility of line managers. Additionally, foreign-owned companies' entrance forced the local companies to 
be less politically oriented; hence, human resource management became crucial. The multinational companies used their advantage of resources over the local companies, thus changing local business systems.

\subsection{Concept of International HRM}

International human resource management has grown significantly over the past few years as a result of globalisation. Collings et al. (2007) posit that this growth can be felt through its empirical and theoretical foundation and practical application. Björkman and Stahl (2006) further suggest that IHRM is a field that is extraordinarily vibrant and prone to continuous development due to new technology and themes that exceed traditional HRM. Stahl et al. (2012) argue that International HRM can be credited to competition in the business environment as global human resource services continue to grow and employees adapt to their services' mobility across borders. Furthermore, innovation and technology are no longer centred in the headquarters but have devolved somewhat to the subsidiary offices. Stahl et al. (2012) defined international HRM as the management of global employees and how it affects their end performance.

Academics and researchers proposed various classifications of international human resource management to distinguish it from local human resource management. De Cieri and Dowling (1999) and Karoliny et al. (2009) outlined three different categories in IHRM, which include the management of human resources in multinational cooperation, the management of different cultural practices and beliefs, and finally, comparative human resource management, which compares HR practices at a national and organisational level. Dowling et al. (2013) broadened the concept of International HRM; he attributes its intricacy to additional human resource services, such as international taxation and language barriers, a broader scope of human resource activities as companies have to design or reorganise their HR programs to fit international standards, professional training and development to enable the expatriate employees to cope, and balancing the workforce in terms of getting a proper blend between the local employees and expatriates. Moreover, it exposes the expatriates to potential risks, such as human and financial risks, and finally, external influences, such as the type and state of government and the economy.

According to Poór (2009), multinational companies are at liberty to opt for various styles of management, such as ethnocentric management, where authorities of the parent company run all the critical managerial positions of a domestic company. Also, polycentric management, where the locals hold managerial positions with limited promotion chances. Region-centric management, where locals hold crucial management positions in their subsidiaries and regional companies, and geocentric management, where locals can hold top management positions in the parent company (Michael et al., 2016).

\section{THE LABOUR MARKET IN HUNGARY}

The workforce in Hungary is highly skilled and educated. The EU's association strengthens its political and economic steadiness, whereas big global companies' aid has decreased the crisis's impact. The size of Foreign Direct Investments that had surged into Hungary since the beginning of the economic transformation was 86 billion USD by the end of 2009. In ploughed revenues, other contributing interests and working capital investments accounted for 60 billion EUR, while other capital accounted for 4.3 billion EUR (Poór et al., 2017). 
The global financial crisis in 2008 had a significant impact on human resource management and practices in Hungary. In response to the direct involvement of HR functions in substituting the less regulated labour force, Individuals with the ability to speak different languages migrated to neighbouring countries since it was easier for multinational companies to substitute between the factors of input. Furthermore, this had a significant impact on industries such as construction, catering, and tourism (Péter, József, 2009; Egedy, 2012). According to the Central Statistical Office in Hungary, there was a slight increase in the labour force between 2015 and 2016. However, employment growth has since reduced, which is attributed to the reduction in the labour force perspective.

Due to technological advancement and dynamic changes, the labour market has shifted towards employing higher-skilled people (Karoly, Morvai, 2018). Its effect reflects the expansion in the service industry, which has changed tact through investing in high valueadded production (OECD, 2016). Therefore, local and multinational companies need to employ highly skilled labour to sustain growth and remain competitive in the Hungarian market (OECD, 2020).

In a bid to improve the labour force, the Hungarian business environment has witnessed various changes in the legislation concerning its labour market policies (such as the modification of the Vocational and Adult Training Act in July 2018, the HRDOP tender framework, the establishment of women in the family and at work, and the pensioners' cooperatives introduced in 2017). However, despite the various policies by the government, the employability rates in Hungary remain relatively low. According to PwC (2018), shrinking and scarcity in the labour market result from the declining unemployment rate and a lack of qualified personnel suitable for employment (due to skilled labour migration).

The Gross Domestic Product (GDP) in Hungary was worth 165.70 billion US dollars in 2020. Hungary's GDP value represents 0.25 percent of the world economy; it averaged 59.23 billion USD from 1968 to 2018, reaching an all-time high of 158 billion USD in 2008 and a record low of 4.69 billion USD in 1968 (World Bank, 2020; Hungarian Central Statistical Office, 2021).

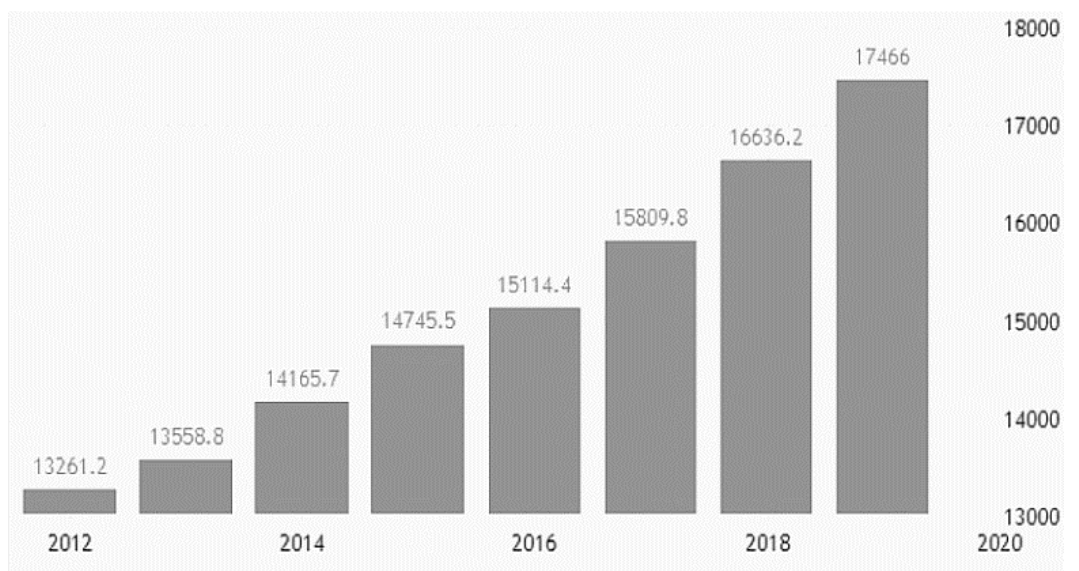

Figure 1. GDP per capita in Hungary (2012-2020)

Source: (Hungarian Central Statistical Office, 2021). 
Figure 1 shows that the Gross Domestic Product per capita in Hungary reached $\$ 17466$ in 2020. Hungary's GDP per capita is $130 \%$ of the international average; it also averaged $\$ 11980$ from 1991 to 2018, peaking at \$17466 in 2020 (World Bank, 2020; Hungarian Central Statistical Office, 2021).

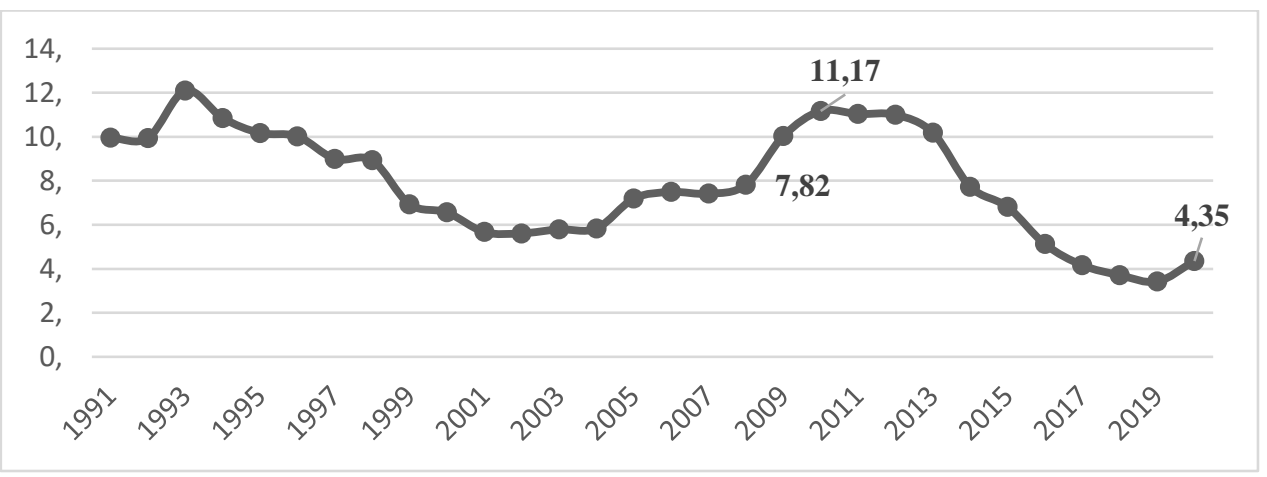

Figure 2. The unemployment rate in Hungary (1991-2021)

Source: (Hungarian Central Statistical Office, 2021).

Moreover, Figure 2 displays a long-term overview of the unemployment rate in the last three decades; it demonstrates that the unemployment rate has increased to its highest level ever after the financial crisis in 2008 ; it went from $7.82 \%$ to $11.17 \%$ in 2010 . However, the unemployment rate has progressed well in the last six years, reaching its lowest value $(3.42 \%)$ in 2019 . As indicated in the graph, the unemployment level in Hungary was $3.5 \%$ in November 2019, which was a $1.1 \%$ decline from the previous year. Recently, Hungary's unemployment rate dropped to $4.1 \%$ in July 2021 , down from $4.6 \%$ in the same period the previous year. Meanwhile, youth unemployment has risen to 51,000. Unemployment lasted an average of 8.8 months, and $34.6 \%$ of the jobless had been searching for work for at least a year.

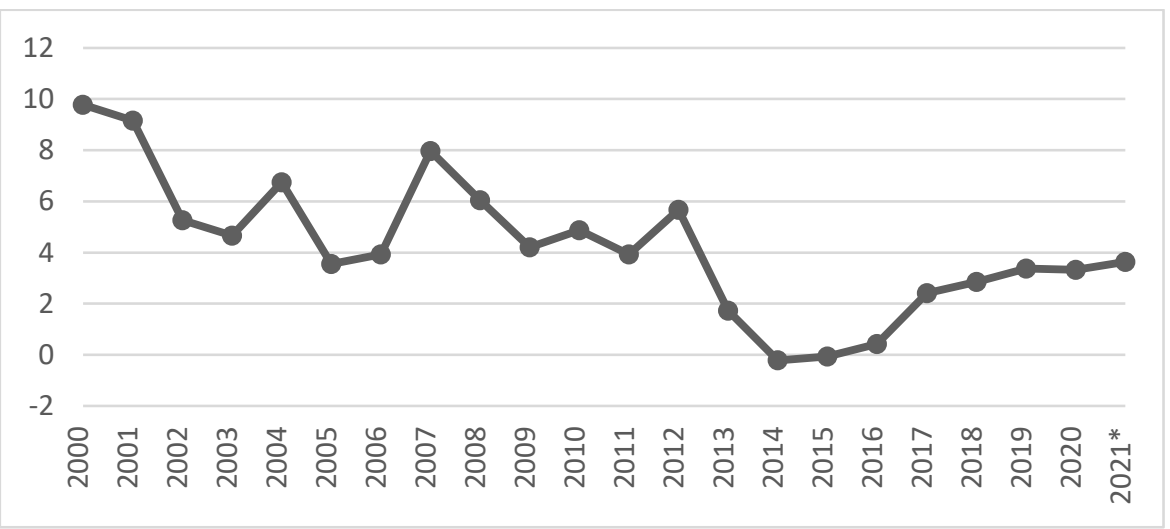

Figure 3. Inflation rate in Hungary (2020)

Source: (Hungarian Central Statistical Office, 2021). 
The figure above demonstrates the average inflation rate in Hungary from (2000-2021). In 2018, the average inflation rate in Hungary reached 2.84 percent compared to the preceding year. The figure shows us a close-up overview of the inflation rate in the last year (2019). It reveals that Hungary's inflation rate mounted to 4.0\% in December 2019 from $3.4 \%$ to November 2019 , above market expectations of $3.8 \%$. This rate is the maximum since December 2012 and continued at the top of the central bank's inflation target range, mainly increased by prices of food and non-alcoholic drinks (5.7\% vs 5.2\%), transport ( $4.0 \%$ vs. $0.1 \%$ ); alcoholic beverages, tobacco $(8.8 \%$ vs $8.6 \%)$; and recreation and culture $(0.9 \%$ vs $0.6 \%)$. As a result, the main inflation enclosed down to $3.9 \%$ from $4 \%$ in November. For 2019 the whole year, the average inflation result is $3.4 \%$.

\subsection{Female in the Labour Force}

According to Fazekas and Morvai (2018), the Hungarian labour reserve (public workers, the underemployed, and the inactive labour force) has been decreasing gradually, making the female labour force the lowest compared to other EU countries. This can be attributed to lower employment rates of women with children under six years of age and the entailment of full leave and other maternity benefits that can last for three years. It is difficult for women with young children to engage in meaningful employment due to the rigid hours of operation of preschools.

According to the OECD (2020), implementing flexible conditions such as flexible working hours will benefit both employees and employers. In addition, the government has incorporated incentives such as lowering social security contributions, maternity benefits, and the exception of working on a part-time basis for working mothers, a move that organisations should emulate.

\section{HUMAN RESOURCE MANAGEMENT PRACTICES IN MULTINATIONAL COMPANIES IN HUNGARY}

Globalisation has had remarkable developments in the complex, dynamic, and diverse international business environment, increasing the consciousness of the importance and critical aspect of the global workforce's management (Stahl et al., 2012). Venegas et al. (2016) argue that international companies' competition leads to the globalisation of the business views in terms of management and integration while still adhering to the local business environment, policies, and practices. Hence, companies with a global network need to employ qualified and competent employees ready to face new challenges and quickly adapt to new environments (Mulang, 2015). International HRM focuses on MNCs' attempt to influence people's work in their operations across borders, and globalisation presents new and significant challenges for managing and regulating work on an international basis.

\subsection{Personnel Management and Corporate Culture}

Large multinational corporations (MNCs) employ $35 \%$ of the private sector workers in Hungary and generate $60 \%$ of GDP and $65 \%$ of exports. There is a lack of understanding about MNC collective bargaining.

Nowadays, Hungary has over 110 international and regional business centres, hiring over 46,000 people in the industry. Businesses provide a very motivating work environment: workers have the opportunity to work in contemporary offices equipped with 
cutting-edge technology. While competence in English is a must for employment in the field, knowing a second foreign language is also frequently required. Daily use of foreign languages is not only required by the nature of the business but is also frequently the case while talking with international team members; Additionally, excellent language skills (possibly more than one), and in some circumstances, a graduate degree. Also, colleagues from other regions work together in teams, providing a productive work atmosphere that allows for insight into one another's daily routines.

Furthermore, the most significant component of the recruiting process is the existence of specified competencies. Strong communication skills, the ability to operate in a team and individually, punctuality and accuracy are among the most crucial attributes. Depending on the task at hand, there may be a variety of resources to deal with, which necessitates the use of a variety of abilities. The individual must also be able to work in an international context, which needs the capacity to prioritise and effectively manage his time.

On the other hand, MNCs set a premium on promoting a positive workplace balance for personnel and accommodating employees with altered working abilities, women's roles, healthy habits, adequate salary and benefits, professional and soft skills training, and career advancement. Flexible schedules are also enticing, with certain professions allowing employees to choose when and where to work and practically every institution supporting several home-office days.

Furthermore, in general, MNCs train their personnel more thoroughly than their local counterparts. Even though retraining might theoretically increase functional flexibility, Hungarian collective agreements (at both domestic and foreign companies) do not address training strategy. As stated in collective agreements, contracts for individual study exclusively cover the terms and circumstances of assistance (such as paid time off and tuition fees) supplied by the company and the responsibilities of employees who receive that support.

\subsection{Social-Economic analysis of Hungary}

Host countries' cultures have a significant and crucial effect on foreign-owned companies' human resource practices and management (Keating, Thompson, 2004; Hofstede, 2005). Hence, it is paramount for global business enterprises to consider the population's cultural aspect when developing and implementing organisational goals and strategies. Hungarian culture is quite different from other cultures in the EU and the neighbouring countries regarding interpersonal relations, familiarity, and creativity (Borgulya, 2011; Németh, Vékás, 2019).

This study conducted the cultural analysis of Hungary, identifying disparities in the business environment. Using the Hofstede data, Hungary's business culture indicates how the economy performs in various parameters, namely Power Distance, Individualism, Masculinity, Uncertainty Avoidance, Long Term Orientation, and Indulgence. Figure 4 shows the main dimensions. 


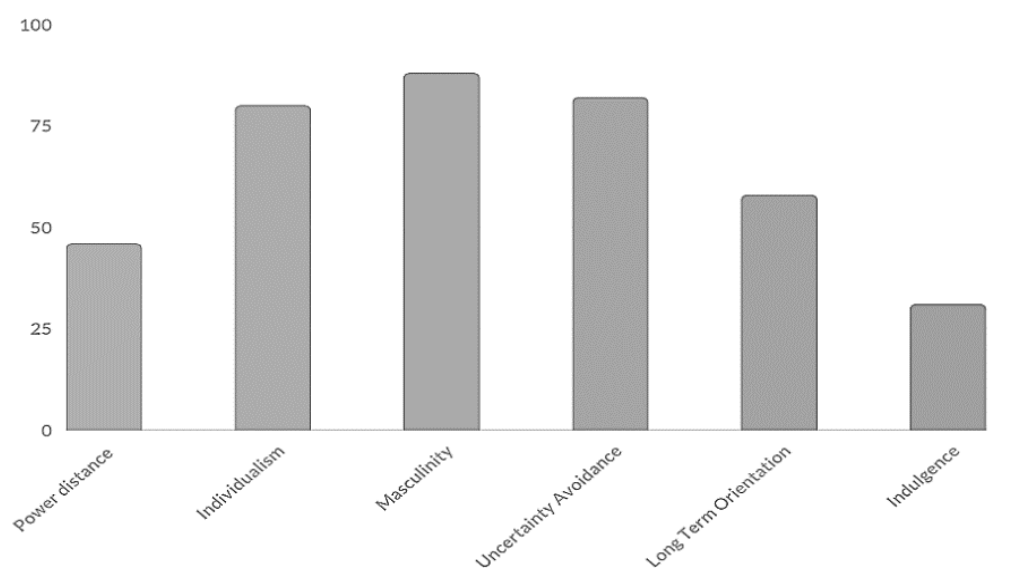

Figure 4. The dimensions of Hungarian culture based on Hofstede's 6-D Model

Source: (Hofstede, 2021).

\section{a) Power Distance}

According to Hofstede, power distance emphasises the fairness or the equality of the population in economies with a higher power distance, indicating a large gap between the haves and the have nots in the society and vice versa. Additionally, the less privileged members of society have to realise that power is unequally distributed. It suggests that the followers approve of inequality in the community, almost like the leaders (Hofstede, 2010; Hofstede, 2021).

Hungary scores 46, which is quite low on this dimension, meaning that the Hungarian cultural society is more independent, power hierarchy is not entrenched in the organisational cultures and is only applied when it is convenient, the supervisors are easily accessible. Also, managers encourage teamwork and consultation of employees on various cadres in the organisation. It is important to note that the Hungarian labour force hates control and prefers direct and participative communication from the management. The power is decentralised, and bosses rely on the experience of their group associates. Hungarian culture is mainly informal as they prefer using their first name to address their seniors. This business culture makes the employment and labour market less intimidating (Hofstede, 2021).

\section{b) Individualism}

Hofstede stated that Individualism refers to the emphasis on interpersonal relationships and achievements, with a high score on Individualism, indicating that a particular economy's business culture is mainly concerned with individual achievement. Individuals in societies that maintain an individualistic business culture tend to have poor interpersonal skills, and thus it becomes difficult to relate with colleagues and business clients. However, low scores in individualism indicate that the population is more open to teamwork and collective responsibility, a culture that extends beyond business to the family level (Hofstede, 2021).

Hungary scores 80 , indicating that the business culture is highly individualistic. The social structure in Hungary is low as individuals only think of themselves and their close family members. In the workplace, this may be detrimental as employees face low 
self-esteem, and the relationship between the employers and the employees is built on a common gain, while hiring and promotion of staff are founded on excellence and performance (Hofstede, 2021).

\section{c) Masculinity}

Masculinity refers to how society views or supports men's traditional roles in an organisation in terms of leadership, control, and achievements. An economy that ranks high on this parameter indicates that there is a high gap in gender responsibilities. Whereby the male gender dominates a substantial part of the economy. A country with low masculinity shows no discrimination in terms of gender, and all genders are treated equally. An equal distribution of duties and responsibilities in any economy is not only beneficial to the organisation but also to the economy at large. A feminine business culture focuses on the quality of employees' lives (Hofstede, 2021).

Hungary scores 88 on this parameter and thus can be termed a Masculine society. This means that in Hungary, the population views work as their mode of survival, meaning that they live to work. In a company setting, proper management is critical as employees are aggressive to remain competitive and improve performance (Hofstede, 2021).

\section{d) Uncertainty Avoidance}

Uncertainty Avoidance focuses on the business culture's perception of risks. A country that rates high uncertainty avoidance shows that the population is risk-averse, hence adhering to strict rules and regulations and laws. However, a country with high scores in uncertainty avoidance implies that society is willing to take risks and readily accept change, especially technological innovation (Hofstede, 2021).

Hungary scores 82 in this parameter, meaning that it is intolerant towards taking risks. Hungarians are punctual, hard-working, precise, and believe in following the rule of law. However, since Hungary is considered risk intolerant, they hardly accept innovation, especially in the ever-changing and dynamic business environment.

\section{e) Long Term Orientation}

Long-term orientation emphasizes the goals of businesses in any society. High scores in long-term orientation indicate that the business culture is oriented towards long-term goals, hence implementing strong business ethics. A country that scores low on the long-term orientation indicates the business culture is geared toward short-term goals and commitments. The goals associated with short-term orientation include respecting society's traditions and fulfilling social responsibilities (Hofstede, 2021). Hungary receives a score of 58 in this parameter, indicating that the country is more hands-on or real, with the population relying on situation and timing. Hungary's population is very flexible and readily accepts changes in the business environment attributed to technological advancement. Additionally, the score indicates that the saving culture is deeply entrenched in the Hungarian population (Hofstede, 2021).

\section{f) Indulgence}

Hofstede used the indulgence parameter to measure the socialisation culture of a country. The indulgence culture is entrenched in the early stages of a child's growth and development. A country whose population cannot control its desires can be termed as indulgent, while a country can control its desires termed as a restraint. In this parameter, 
Hungary scores 31 , indicating that Hungarian culture is restrained. Hence, the population is more work-oriented and does not focus on leisure activities (Hofstede, 2021).

\section{FOREIGN DIRECT INVESTMENTS IN THE CEE REGION}

The CEE region witnessed an increase in FDI inflows until the global financial crisis, which led to a sharp decline. According to Popescu (2014), low labour costs motivate FDIs by foreign or multinational companies. Due to low production costs, cheap resources, and skilled workers, CEE countries experienced similar FDI movements after the transition period and for the better part of the early 2000s (Lrincz, 2018). Additionally, Radulescu et al. (2019) observed that, except for Hungary and the Czech Republic, low wages in other CEE countries were an added advantage in attracting FDIs.

However, FDI values in the CEE countries vary depending on how the author groups the countries (Engle et al., 2020). We compare the FDI inflows and outflows between Hungary and a few selected CEE countries (Czech Republic, Estonia, Latvia, Lithuania, Poland, Slovak Republic, and Slovenia) using the OECD Foreign Direct Statistics 2021. Poland and Hungary had experienced a gradual but not consistent increase in FDI inflows of approximately USD 13.7 million and USD 6.7 million, respectively, by the end of 2020 . However, the Slovak Republic and Slovenia recorded low FDI inflows in 2020, with the Slovak Republic recording the lowest value of approximately USD 1.9 million, as shown in the table below.

Table 1. FDI inflows of selected CEE Countries

\begin{tabular}{|l|r|r|r|r|r|}
\hline & $\mathbf{2 0 1 6}$ & $\mathbf{2 0 1 7}$ & $\mathbf{2 0 1 8}$ & $\mathbf{2 0 1 9}$ & $\mathbf{2 0 2 0}$ \\
\hline Czech Republic & 9,814 & 9,518 & 11,010 & 10,109 & 6,292 \\
\hline Estonia & 1,058 & 1,947 & 1,516 & 3,184 & 3,388 \\
\hline Hungary & $-5,439$ & 3,514 & 6,460 & 4,105 & 6,722 \\
\hline Latvia & 253 & 708 & 963 & 902 & 1,011 \\
\hline Lithuania & 302 & 1,019 & 976 & 3,022 & 3,484 \\
\hline Poland & 16,596 & 9,537 & 16,376 & 13,326 & 13,650 \\
\hline Slovak Republic & 805 & 4,008 & 1,643 & 2,511 & $-1,926$ \\
\hline Slovenia & 1,245 & 896 & 1,383 & 1,463 & 205 \\
\hline
\end{tabular}

Source: (OECD-Foreign Direct Investment Statistics, 2021).

Table 2. FDI Outflows of selected CEE Countries

\begin{tabular}{|l|r|r|r|r|r|}
\hline & $\mathbf{2 0 1 6}$ & $\mathbf{2 0 1 7}$ & $\mathbf{2 0 1 8}$ & $\mathbf{2 0 1 9}$ & $\mathbf{2 0 2 0}$ \\
\hline Czech Republic & 2,182 & 7,557 & 8,663 & 4,128 & 3,142 \\
\hline Estonia & 486 & 888 & 45 & 1,966 & 219 \\
\hline Hungary & $-8,272$ & 1,220 & 3,363 & 3,238 & 4,286 \\
\hline Latvia & 160 & 138 & 203 & -104 & 269 \\
\hline Lithuania & 43 & 80 & 704 & 1,746 & 2,868 \\
\hline Poland & 12,389 & 1,908 & 1,239 & 1,674 & 1,104 \\
\hline Slovak Republic & 95 & 1,323 & 291 & 43 & 235 \\
\hline Slovenia & 290 & 338 & 281 & 610 & 508 \\
\hline
\end{tabular}

Source: (OECD-Foreign Direct Investment Statistics, 2021). 
Hungary, Czech Republic, and Lithuania recorded the highest FDI outflows in 2020 of approximately USD 4.3 million, 3.1 million, and 2.9 million, respectively. However, Estonia recorded the lowest FDI outflows of USD 219 in 2020, an $88.9 \%$ decline from 2019.

\subsection{Foreign Direct Investment and GDP in the CEE Region}

After agreeing to join the European Union, the CEE region attracted high volumes of FDI inflows, hence achieving high economic growth (Radulescu et al., 2019). According to Hlavacek and Domanska (2016), higher FDIs impacted economic growth in Hungary, the Czech Republic, and the Slovak Republic in 2016, while Slovenia and Poland experienced a lower FDI impact on economic growth. However, the CEE region has noted a gradual increase in FDI stocks as a share of GDP (OECD, 2021). Estonia, the Czech Republic, and Hungary had the highest FDI stocks as a share of GDP in 2020. Since 2016, Estonia has seen high growth. Nevertheless, Slovenia recorded a slight increase, but the lowest FDI stock share of GDP from 2016 to 2020.

Table 3. FDI and GDP of selected CEE Countries

\begin{tabular}{|l|c|c|c|c|c|}
\hline \multicolumn{1}{|c|}{ As a share of GDP $(\boldsymbol{\%})$} & $\mathbf{2 0 1 6}$ & $\mathbf{2 0 1 7}$ & $\mathbf{2 0 1 8}$ & $\mathbf{2 0 1 9}$ & $\mathbf{2 0 2 0 p}$ \\
\hline Czech Republic & 62 & 71 & 66 & 68 & 77 \\
\hline Estonia & 79 & 87 & 80 & 88 & 110 \\
\hline Hungary & 64 & 65 & 57 & 57 & 65 \\
\hline Latvia & 51 & 58 & 51 & 53 & 61 \\
\hline Lithuania & 38 & 41 & 36 & 43 & 53 \\
\hline Poland & 40 & 45 & 39 & 40 & 42 \\
\hline Slovak Republic & 53 & 62 & 57 & 58 & 61 \\
\hline Slovenia & 31 & 34 & 32 & 34 & 38 \\
\hline
\end{tabular}

Source: (OECD-Foreign Direct Investment Statistics, 2021).

In a nutshell, according Berber et al. (2017) and Karoliny et al. (2009), the primary areas of similarities and differences in terms of the importance of the human resource function and the role of the human resource department across the CEE countries, defining them as a distinct HR cluster, are that the labour cost ratio is relatively low and that the influence of local offices and establishment policies is perceived to be strong in large companies. Also, the use of external human resource service providers in the areas of pay and benefits, workforce reduction, and one noteworthy distinction between Hungary and the remaining CEE countries on this topic is that line managers were stated to have a much greater role in and main responsibility for all HR functions assessed than any other decision-makers who have influence over HR strategies.

\subsection{Foreign Direct Investments and Employment}

The intrinsic nature of Foreign Direct Investment (FDIs) is to get control of a company's assets and operations in other countries (Poór et al., 2017). The Central and Eastern European countries were ranked as the third most attractive foreign investment location after Western Europe and China (Lőrincz, 2018).

According to Poór et al. (2017) and Lörincz (2018), FDI is essential for economic growth, development, and employment, particularly in the CEE countries. Previous studies 
have shown that FDI inflows positively influence employment and wages (Golejewska, 2002; Jenkins, 2006). The United Nations' UNCTAD (2021) reports that employment by foreign affiliates was at approximately 86 million people in 2018 . However, according to Poór et al. (2017), the employment of workers by MNCs in their subsidiaries varies across countries.

Foreign Direct Investments (FDIs) have played a dynamic role in the successful reformation of the Hungarian economy after collapsing the previous system in 1990. As a result, Hungary has one of the best open economies in the area. It has enabled yield growth, technological innovation, and export capability. Hence, it is crucial for solid growth potential and new opportunities (Hungarian Central Statistical Office, 2021). As a result, Hungary has sustained its position as an eye-catching investment target. Besides, it is broadly considered the gateway to Central and Southeast Europe, making it an attractive foreign investment market.

Furthermore, FDIs play a very crucial role in economic growth and employment, especially in EU countries. For example, in Hungary, international companies' subsidiaries began penetrating in 1988 due to foreign investors eyeing partnership opportunities with the local companies. This move led to the gradual growth of foreign direct investment and employment (Poór et al., 2014).

Hungary has one of the highest rates of FDI stock per capita in Central and Eastern Europe. Moreover, the Hungarian FDI stock represents the highest percentage of GDP $(82.2 \%)$ in the Central European region. At the end of 2018, Hungary's FDI stock stood at EUR 88.7 billion (Santander, 2019; Hungarian Central Statistical Office, 2021).

Table 4. Foreign Direct Investments (2017-2019)

\begin{tabular}{|l|c|c|c|}
\hline Foreign Direct Investment & 2017 & 2018 & 2019 \\
\hline $\begin{array}{l}\text { FDI Inward Flow (million } \\
\text { USD) }\end{array}$ & 3,502 & 8,365 & 5,205 \\
\hline FDI Stock (million USD) & 93,619 & 95,787 & 97,841 \\
\hline $\begin{array}{l}\text { Number of Greenfield } \\
\text { Investments }\end{array}$ & 83 & 114 & 102 \\
\hline $\begin{array}{l}\text { Value of Greenfield } \\
\text { Investments (million USD) }\end{array}$ & 3,055 & 4,894 & 7,515 \\
\hline
\end{tabular}

Note: Greenfield Investments is an investment type in which a parent firm starts a new business in a foreign country by constructing new operating facilities from scratch*

Source: (UNCTAD, 2020).

Hungary retains a high per capita foreign direct investment (FDI) stock for Central and Eastern Europe. Nevertheless, the crisis in 2009 has profoundly impacted FDI flows to Hungary, and since that time, the size of inward FDI flows has been smaller. Nevertheless, FDI backed up in 2018 to reach USD 6.3 billion, nearly doubled. In addition, Hungary approved a new law, presenting a foreign investment screening mechanism related to national security in some sectors such as defence, products, utilities, the financial industry, electronic communication, and public communication systems.

Most FDI inflows were capitalised in manufacturing ("equipment, electronic, automotive, chemistry"). Based on the "World Investment Report 2019", stock was reduced by $2 \%$, reaching $\$ 88$ billion in 2018 (57\% of GDP). Table 1 below shows the vital investing 
countries: Germany, the Netherlands, Luxembourg, Ireland, the US, France, and South Korea. FDI mainly focuses on manufacturing, trade, personal, scientific, and technical activities, and financial support.

In recent years, Hungary has encouraged FDI to shift away from low-value textile and food-processing sectors and toward wholesale, retail trade, and vehicle repair. Nevertheless, the country's demographic decline and the education system's slow progress hamper vital structural transformation. Furthermore, the Hungarian government approved an investment screening law, which came into force at the beginning of 2019 on the back of security concerns.

Table 5. Flows of foreign direct investments by country and industries.

\begin{tabular}{|c|c|}
\hline Main Investing Countries & 2020, in \% \\
\hline Germany & 13.0 \\
\hline Netherlands & 10.3 \\
\hline Luxembourg & 10.1 \\
\hline Ireland & 9.4 \\
\hline United States & 9.1 \\
\hline France & 7.5 \\
\hline South Korea & 6.7 \\
\hline
\end{tabular}

Source: (Central bank of Hungary, 2020).

Figure 5 below shows the main sectors of investment among foreign-owned companies in Hungary. It displays that the manufacturing sector occupies the largest quota of the foreign market share, at $38 \%$, followed by wholesale trade and the vehicle sector at $13.7 \%$. On the other hand, $6.1 \%$ for professional and technical services and the lowest share goes to monetary intermediation (Central bank of Hungary, 2020).

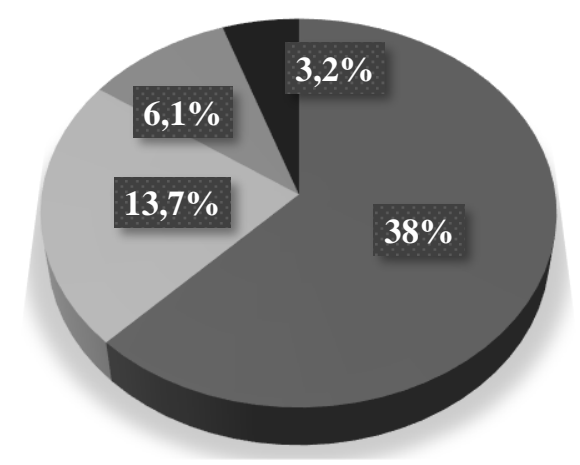

\author{
- Manufacturing \\ Wholesale and retail trade; \\ repair of vehicles \\ - Profesionnal, scientific, \\ technical activities and other \\ services
}

- Monetary intermediation

Figure 5. Main Invested Sectors in Hungary 2020

Source: (Central Bank of Hungary, 2020). 


\subsection{Strong Aspects for FDI in Hungary}

Hungary is widely considered the gateway to Central and Southeast Europe, making it an attractive foreign investment market. The workforce in Hungary is highly educated and competent, with a particular emphasis on engineering, medicine, and the economy. There has been a literacy rate of $99.1 \%$ since 2015 . Despite a temporary slowdown in 2015 , Hungary's economy remains one of the fastest growing in the EU. Its banking system is one of the region's most advanced. Its infrastructure, workforce, and regulatory framework are of excellent quality and offer significant supply chains in the automotive and electronics industries. Moreover, the EU funds have continued to expand since 2004.

With the assistance of major international organizations, EU integration improved political and economic stability while mitigating the effects of the crisis. The National Development Plan 2014-2020 allocates EUR 6 billion to additional tourism, health, infrastructure, and environmental protection programs. Multinational and foreign-owned companies gain entrance to other countries for traditional reasons but seek to balance the apportionment of resources and improve economies of scale by moving their activities to countries considered to be low-cost (Dowling et al., 2013). The entry of foreign-owned firms into any economy is considered the motivation towards globalisation which significantly impacts corporate human resource activities (Venegas et al., 2016). Therefore, it can be argued that the substantial effect of IHRM today is attributed to the changes in foreign direct investment globally.

After World War II, the international business environment changed drastically, especially with American companies entering practically all countries globally. This saw an expansion of cross-border business and economic activities, leading to developed and developing countries' economic growth. According to Hill (2019), there is a strong and positive correlation between FDI and various economies' economic development. Economies witnessed a gradual increase in FDIs until the 2008 financial crisis, which resulted in a drop in reserve trends and other indicators such as foreign trade and employment (Poór et al., 2014; UNCTAD, 2020). Currently, FDI flows are more inclined towards the developed economies, unlike previously, where the flows were mainly intense in the developing economies (Collings et al., 2007).

Ultimately, according to the OECD (2020) report, FDI in Hungary has continued to increase, thus positively impacting the production capacity, especially in the country's central and western parts. Hungary's FDIs are mainly from multinational companies that move their production activities intended for Hungary's global markets. That has been encouraged by reducing the Hungarian government's corporate tax to boost business investments, especially from multinational companies. Moreover, in the fourth quarter of 2020, Hungarian foreign direct investment grew by EUR 1606.50 million (National Bank of Hungary, 2021).

\section{CONCLUSION}

International HRM has grown significantly with the entry of multinational companies. Recently, the Hungarian population and business community have become cognizant that human resource management is crucial in the running and success of any organisational performance. This has compelled organizations to create and adopt more systematic and strategic human resource management and practice approaches, putting Hungary's HRM 
practices above those of other countries in the Central and Eastern European countries (Németh and Vékás, 2019).

The presence of multinational companies has a significant impact on the economic growth and development, employment, and human resource practices of host countries. The Central and Eastern European regions were the hub for attracting foreign investors. This was attributed to low labour costs, low production costs, and growth opportunities compared to Western European countries. However, this changed after the global financial crisis. Its impact was closely felt in Hungary as the Hungarian population, which possessed the ability to speak different languages, migrated to neighbouring countries since it was easier for multinational companies to substitute between the factor inputs. As a result, the CEE region, particularly Hungary, has been gradually recovering from the global financial crisis to try and restore its former glory and position itself as the most attractive country for foreign companies to invest in.

The study, therefore, sought to examine the HRM practices of foreign-owned companies and Hungary's socioeconomic environment. The study found Hungary to be an attractive foreign investment market because, first, Hungary is not only broadly considered the gateway to Central and Southeast Europe but also because the Hungarian workforce is composed of highly skilled workers. Second, the social-cultural aspect, where the Hungarian cultural society is more independent, power hierarchy is not entrenched in the organisational culture, highly individualistic, masculine, intolerant towards taking risks, realistic, and culturally restrained. And lastly, the FDIs. The study analysed Foreign Direct Investments in Hungary in comparison to selected countries in the CEE region. The study found that Hungary had high FDI stocks in GDP and high FDI inflows during 2020. However, the FDIs in Hungary is mainly from multinational companies that move their production activities intended for Hungary's global markets.

For companies to remain in the global market, developing innovative ideas that are distinct from rivals is essential. In addition, changes in economic, cultural, and technological shifts are causing new organisational demands that push human resources in new ways. HR experts believe that globalisation, increasing generational differences, and an increased focus on innovation and sustainability are all causing major shifts in how organisations operate (Hitka et al., 2017). Eventually, this study recommends further research on how the COVID 19 pandemic has affected multinational companies, particularly with the introduction of work-from-home policies.

\section{REFERENCES}

Bembenek, B. (2014). The Importance of Organisational Culture in Cluster Management. “Modern Management Review”. DOI: 10.7862/rz.2014.43.

Berber, N., Morley, M. J., Slavić, A., Poór, J. (2017). Management compensation systems in Central and Eastern Europe: a comparative analysis. "The International Journal of Human Resource Management”, 28(12). DOI: 10.1080/09585192.2016.1277364.

Björkman, I., Stahl, G. (2006). International Human Resource Management Research: An Introduction to the Field'. Handbook of Research in International Human Resource Management, Cheltenham: Edward Elgar.

Borgulya, I. (2011). Similarities and Differences in Cooperation and Communication of Eastern-Europeans [In:] Poór, J., Bóday, P., Kispál-Vitay, Zs., Eds, Trends and tendencies 
in human resource management in Eastern Europe [in Hungarian] (p. 43-61). Budapest: Gondolat Publishing House.

Central Bank of Hungary (2020). Foreign Direct Investments [access: 23.01.2021]. Access on the internet: https://www.mnb.hu/en/statistics/statistical-data-and-information/statisticaltime-series/

Chegri, M., Rigalma, H. Torra, M. (2021). Management Control System in the context of SMEs. “Modern Management Review”, 26(3). DOI: 10.7862/rz.2021.mmr.16.

Collings, D.G., Scullion, H., Morley, M. J. (2007). Changing Patterns of Global Staffing in The Multinational Enterprise: Challenges to the Conventional Expatriate Assignment and Emerging Alternatives. "Journal of World Business", 42. DOI: 10.1016/j.jwb.2007.02.005.

De Cieri, H., Dowling, P. (1999). Strategic Human Resource Management in Multinational Enterprises: Theoretical and Empirical Developments [In:] Wright, P., Dyer, L., Boudreau, J., Milkovich, G., Eds., Strategic Human Resource Management: An Agenda for the 21st Century. JAI Press, Greenwich, CT.

Dowling, P. J., Festing, M., Engle, A. D. (2013). International Human Resource Management. $6^{\text {th }}$ ed. London: Thomson-Cengage. DOI: 10.1007/s11575-014-0236-1.

Egedy, T. (2012). The effects of global economic crisis in Hungary. „Hungarian Geographical Bulletin”, 61.

Engle, A. D., Zaharie, M., Kerekes, K., Poór, J. (2020). Who Is in Charge Here? Evidence of the Division of Roles and Responsibilities Between Global and Local HR Managers in MNEs Operating in the CEE Region. "Journal of East-West Business", 26(1). DOI: 10.1080/10669868.2019.1689218

Golejewska, A. (2002). Foreign Direct Investment and its employment effects in Polish manufacturing during transition. "Analizy i Opracowania KEIE UG”.

Hill, C. (2019). International Business: competing in the global marketplace. New York, Ny Mcgraw-Hill Education.

Hitka, M., Lorincová, S., Ližbetinová, L., Schmidtová, J. (2017). Motivation Preferences of Hungarian and Slovak Employees are Significantly Different. "Periodica Polytechnica Social and Management Sciences”, 25(2). DOI: 10.3311/ppso.10052.

Hlavacek, P., Domanska, B. (2016). Impact of foreign direct investment on economic growth in Central and Eastern European Countries. "Inzinerine Ekonomika - Engineering Economics", 27(3).

Hofstede, G., Hofstede, G. J. Minkov, M. (2010). Cultures and Organisations: Software of the Mind. Third Edition. Amazon Sales Rank. DOI: 10.1177/0022022110388567.

Hofstede, G., Hofstede, G.J. (2005) Cultures and Organisations: Software of the Mind Revised and Expanded 2nd Edition. New York: McGraw Hill.

Hofstede, G. (2021). Hofstede Insights- Cultural Dimensions. Hofstede Insights. Access on the internet: https://www.hofstede-insights.com/product/compare-countries/

Hrehová, D., Cehlár, M. (2015). Quality human resources are most precious for the company [In:] International Multidisciplinary Scientific Geo Conference and EXPO, SGEM 2015, Albena, Bulgaria.

Hungarian Central Statistical Office (2021): STADAT Tables [access: 22.07.2021]. Access on the internet: http://www.ksh.hu/stadat_eng

Jenkins, R. (2006). Globalization, FDI and Employment in Vietnam. "Transnational Corporations" 15(1). 
Karoliny, Z., Farkas, F., Poór, J. (2009). In Focus, Hungarian and Central-Eastern European Characteristics of Human Resource Management - An International Comparative Survey. “Journal for East European Management Studies”, 14(1). DOI: 10.5771/0949-6181-2009$1-9$.

Karoly, F., Morvai, A.S. (2018). The Hungarian Labour Market. Institute of Economics, Centre for Economic and Regional Studies. Budapest: Hungarian Academy of Sciences.

Keating, M., Thompson, K. (2004). International Human Resource Management: Overcoming Disciplinary Sectarianism. "Employee Relations", 26(6). DOI: 10.1108/ 01425450410562191.

Lőrincz, N. (2018). Being an investment target in CEE. Country attractiveness and nearshoring. "Vezetéstudomány/Budapest Management Review", 49(5). DOI:10.14267/ veztud.2018.05.05.

Mazur, B., Walczyna, A. (2020). Bridging Sustainable Human Resource Management and Corporate Sustainability. "Sustainability”, 12(21). DOI: 10.3390/su12218987.

Michael, M., Poór, J., Heraty, N., Alas, R., Pocztowski, A (2016). Developments in Human Resource Management in Central and Eastern Europe in Comparative Perspective [In:] Brewster, Ch., Dickmann, M., Sparow, P., International Human Resource Management, 3rd Contemporary HR Issues in Europe. New York: Taylor and Francis.

Mulang, A. (2015). The Importance of Training for Human Resource Development in Organization. "Journal of Public Administration and Governance", 5(1). DOI: 10.5296/ jpag.v5i1.7505.

National Bank of Hungary (2021). Foreign Direct Investment [access: 04 May. 2021]. Access on the internet: http://www.mnb.hu

Németh, A., Németh, P., Vékás, P. (2019). Demographics, Labour Market, and Pension Sustainability in Hungary. "Society and economy", 42(2). DOI: 10.1556/204.2019.015.

OECD (2016). Economic Surveys. Hungary. OECD Publishing, Paris.

- (2020). OECD Economic Surveys: Hungary, OECD Publishing.

OECD - Foreign Direct Investment Statistics (2021) [access: 29.11.2021]. Access on the internet: https://www.oecd.org/investment/statistics.htm

Peter J., Dowling, M. F., Allen D. E. (2013). International Human Resource Management 6th Edition, Cengage Learning EMEA. DOI: 10.1080/09585192.2015.1041761

Péter, F., József, P. (2009). The Impact of The Economic and Financial Crisis on HRM and Knowledge-Management in Hungary and Slovakia - Empirical Research 2008-2009. “Acta Polytechnica Hungarica”, 6. DOI: 10.3311/pp.so.2012-1.04.

Poór, J. (2009). Managing human resources in Hungary. In M. J. Morley, N. Heraty, \& S. Michailova (Eds), Managing human resources in Central and Eastern Europe (p. 188-218). New York: Routledge.

Poór, J., Engle, A. D., Brewster, C. (2017). HRM in Transition-practices of MNC-subsidiaries in Central and Eastern Europe, Russia and Kazakhstan (2015-2016). J. Selye University.

Poór, J., Engle, A. D., Szlávicz, A., Kerekes, K., Szabó, K., Kovács, I.E., Józsa, I., eds. (2015). Human Resource Management Issues and Challenges in Foreign Owned Companies: Central and Eastern Europe (2011-2013).

Poór, J., Karoliny, Z., Dobrai, K., Slavic, A., Kerekes, K., Farkas, F., Engle, A. D. (2014). Factors Influencing Human Resource Management Solutions at Subsidiaries of Multinational Companies in Central and Eastern Europe. "Journal of East-West Business", 20(2). DOI: 10.1080/10669868.2014.897288 
Popescu, G. H. (2014). FDI and economic growth in Central and Eastern Europe. "Sustainability" (Switzerland), 6(11),8149-8163. DOI: 10.3390/su6118149

Radulescu, M., Serbanescu, L., Sinisi, C. I. (2019). Consumption vs. Investments for stimulating economic growth and employment in the CEE Countries - a panel analysis. "Economic Research-Ekonomska Istrazivanja”, 32(1). DOI: 10.1080/1331677X.2019.1642789.

Santander (2019). Hungary: Foreign Investment [access: 28.07.2021]. Access on the internet: https://santandertrade.com/en/portal/establish-overseas/hungary/foreign-investment

Scullion, H., Collings, D. G., Gunnigle, P. (2007). International Human Resource Management in the 21st Century: Emerging Themes and Contemporary Debates. "Human Resource Management Journal”, 17. DOI: 10.1111/j.1748-8583.2007.00047.x.

Stahl, G., Morris, S. (2012). Handbook of Research in International Human Resource Management. Edward Elgar Publishing Ltd. USA. ISBN: 9781849809184.

Thill, K., Venegas, B.C., Poór, J. (2016). HR Positioning - A Matter of National Culture? Facts from Hungary. "Business Perspectives and Research" 4(2). DOI: 10.1177/ 2278533716642642.

UNCTAD (2020). World Investment Report (United Nations Conference on Trade and Development) [access: 04.07.2021]. Access on the internet: https://unctad.org/topic/ investment/world-investment-report

Venegas, C., Thill, B., Rašticová, K., József, P., Zdeňka, K. (2016). Examining the Roles of Human Resource Management in Foreign-Owned Firms: Focus on Three CEE Countries and Austria. "European Journal of Business Science and Technology", 2(1). DOI: 10.11118/ejobsat.v2i1.21

Wolfe, J., Poór, J. (1992). Socio-Economic Note Hungary 1990 and Mechanical Tools Factory. [In:] Wheeler, T. L., Hunger, D. J., Eds, Strategic management and business policy (p. 1014-1061). Boston: Addision-Wesley Publishing Co.York: McGraw-Hill.

World Bank (2018). World Bank Group - International Development, Poverty, \& Sustainability [access: 07.01.2021]. Access on the internet: https://www.worldbank.org

Worldatlas (2017). Hungary Facts on Largest Cities, Populations, Symbols - Worldatlas.com. [access: 23.07.2021]. Access on the internet: https://www.worldatlas.com/webimage/ countrys/europe/hungary/hufacts.htm\#page

Worldometers (2021). Worldometers - real time world statistics [Access: 04.07.2021]. Access on the internet: https://www.worldometers.info/world-population/hungary-population.

DOI: $10.7862 /$ rz.2021.mmr.21

The text was submitted to the editorial office: October 2021.

The text was accepted for publication: December 2021. 